\title{
Contemporary Study of Ihtikar According to Scholars and the Effect of ihtikar practices in the Economy
}

\author{
1*Ahmad Maulidizen, ${ }^{2}$ Nur Atikah, ${ }^{3}$ Yuni Sahara \\ ${ }^{1,2,3}$ Department of Shariah Business and Management, STEI Tazkia, Indonesia \\ *Email korenpondensi: ahmadmaulidizen@tazkia.ac.id
}

\begin{abstract}
Ihtikar is a sale and purchase transaction which fulfills the terms and conditions in the sale and purchase contract, but is included in prohibited transactions. In practice, many people are still confused about the ihtikar problem. There are differences regarding the law and the object of Ihikar as transactions that are prohibited from social and economic interests. Therefore, this article will explain the ihtikar law according to scholars and the impact of its application on the economy. This article is a central study with qualitative assessment, a method of collecting data with documentation originating from journals, books and other sources, which are then analyzed by inductive, deductive and comparative methods. The results of the study found that the verses and hadith raised in this paper textually prohibit the existence of ihtikar. Ihtikar law is haram if the goods stockpiled are needed by the community which results in price increases. When this happens, Islam allows for intervention in these economic activities by issuing policies and rules that affect normal prices.
\end{abstract}

Keywords: Contemporary study of ihtikar; Scholar views; the effect of the economy

\begin{abstract}
Abstrak
Ihtikar merupakan transaksi jual beli yang mana memenuhi syarat dan rukunnya dalam akad jual beli, namun termasuk dalam transaksi yang dilarang. Dalam peraktiknya banyak sebagian masyarakat yang masih bingung mengenai pemasalahan ihtikar. Terdapat perbedaan mengenai hukum dan objek ihtikar sebagai transaksi yang dilarang atas kepentingan sosial dan ekonomi. Oleh karena itu, artikel ini akan menjelaskan hukum ihtikar menurut ulama dan dampak aplikasinya terhadap ekonomi. Artikel ini merupakan kajian pusataka dengan pendektan kualitatif, metode pengumpulan data dengan dokumentasi berasal dari jurnal, buku dan sumber lainnya, yang kemudian di analisis dengan metode induktif, deduktif dan komparatif. Hasil kajian mendapatkan bahwa ayat dan hadis yang diangkat dalam tulisan ini secara tekstual melarang adanya ihtikar. Hukum ihtikar adalah haram jika barang yang ditimbun sangat diperlukan masyarakat yang berakibat terjadinya kenaikan harga. Ketika hal demikian terjadi, Islam membolehkan adanya intervensi terhadap aktivitas ekonomi tersebut dengan mengeluarkan kebijakan dan aturan yang berdampak pada harga yang normal.
\end{abstract}

Kata kunci: Kajian kontemporer ihtikar; pandangan ulama; dampak ekonomi

Saran sitasi: Maulidizen, A., Atikah, N., \& Sahara, Y. (2019). Contemporary Study of Ihtikar According to Scholars and the Effect of ihtikar practices in the Economy. Jurnal Ilmiah Ekonomi Islam, 5 (02), 89-101. doi: http://dx.doi.org/10.29040/jiei.v5i2.520

DOI: http://dx.doi.org/10.29040/jiei.v5i2.520

\section{Introduction}

Islam is a perfect religion. Provide complete

life guidance for humans in establishing a relationship, both to the creator, humans, animals, plants and even the entire face of the earth. Mutual relations between humans as social 
beings have been arranged so as not to cause problems that lead to instability in life. The case of meeting the needs of a good life has been discussed in the Quran, Hadith and the scholars for the completion and legal provisions. Buying and selling is one of the economic activities regulated in Islam as one of the legal rules contained in the rules between individuals as social beings who need each other between each other, namely Islamic transaction (figh muamalah). This activity is a means to meet needs and gain benefits in facing life. On buying and selling, there are terms and conditions which result in the validity or non-validity of the transaction. The law aims to prevent conflicts and disputes between parties who transact, maintain the rights and benefits of both parties, and eliminate all forms of uncertainty and risk (Djuwaini, 2008).

The difficulty of economic life that occurs in the community results in the emergence of buying and selling transactions that are not appropriate and violate existing legal rules only to fulfill the wishes of one party. Either by fraud, coercion or hoarding of goods. Stockpiling of goods or in terms of fiqh is called ihtikar and sometimes known as monopoly. The reality of the impact of ihtikar resulted in only one seller controlling the market for the sale and purchase of the goods so that the ihtikar was equated with monopoly. This activity is a legitimate sale and purchase transaction because it meets the terms and conditions, but includes prohibited sale and purchase. The prohibition is because it is not in accordance with social objectives, namely the priority of benefits for both parties, not one of the parties. Hoarding of treasure or Ihtikar is an activity that has been clearly prohibited and threatened with severe sanctions in the Qur'an in the letter Al-Humazah [104]: 1-4 and Al-Taubah [9]: 34-35. Ihtikar is a case that causes serious problems because it affects many people. This paper will discuss ihtikar according to scholars and economics.

\section{Research Methods}

This research is a library research with descriptive approaches, which are describing or explaining the analysis of contemporary study of Ihtikar according to scholars and the effect of ihktikar practices in the economy. The method of collecting data in this study is documentation, journals and books. Then analyzed using content analysis, which is by analyzing library data that is desktiptive or scientific analysis of the message premise. Data analysis methods are deductive, inductive and comparative.

\section{Results and Discussion}

\subsection{Definition of Ihtikar}

Language Ihtikar is the act of hoarding, collecting items or a place to hoard (Rohman, 2017). Ihtikar is a form of mashdar, while the form of madhi can be read hakira or hakara. In Mu'jam Maqayis Lughah, the word hakara is interpreted as al-habs (holding). While the law is holding food while waiting for the scarcity of food. Meanwhile Ibn Manzhur interpreted the meaning of hakara by storing food to eat. Whereas ihtikar is collecting food and other edible items, then being held back to wait for the price to rise. Ibn Manzhur also quoted the opinion of Ibn Sayyidah stating that ihtikar is collecting food and other edible items, then holding it until at times there is difficulty in finding the ingredients. Meanwhile according to Al-Azhari the word hakara means injustice, destruction and bad association. From this language understanding, it can be seen that the main element in ihtikar is the aspect of restraining and storing (al-habs wa al-iddikhar). If there is no aspect, then the item is not called ihtikar.

Whereas other aspects such as goods that are objects of savings are not the main aspects, but only become part of that aspect. Therefore, it is only natural that differences regarding goods are considered ihtikar, but there is agreement regarding their storage. (Muslim, 2011) Whereas in terms of, ihtikar is buying goods that exceed the needs with the aim of hoarding them, 
dominating the market and selling at high prices at will when the general public needs them (Tarmizi, 2018) Here are some definitions according to some scholars, namely: 1 . According to the Syafi'i, ihtikar is selling raw materials when prices rise and hold them or store them so that the selling price will increase later, (2) Hanafi, Ihtikar, everything that can cause mudhorot for people in a particular region or country or community environment in the form of food, clothing, dinar and dirham money, (3) Maliki, ihtikar is hiding certain items in the market which aims to obtain a high price advantage, (4). Hanbali, ihtikar is the stockpiling of goods obtained through purchase when the condition of the community is in need requires a narrowing of the movement of the community in obtaining the goods, so that it will affect the economy of the community in that area, and (5) Adiwarman Karim, Ihtikar is taking advantage of normal profits by selling fewer items for high prices, or the economic term is called monopoly rent. (Rohman: 2017), (6) Sayyid Sabiq, ihtikar as buying an item and storing it so that the goods are reduced in the community so that the price increases so that people will get difficulties due to scarcity and high prices (Sabiq: 1984), and (7) Fathi al-Duraini, ihtikar with the act of storing property, benefits or services, and is reluctant to sell and give it to others which results in a drastic increase in market prices due to limited inventory or goods stock completely missing from the market while people, countries, or animals (livestock) really need these products, benefits, or services. ihtikar according to alDuraini is not only about commodities, but the benefits of a commodity and even the services of a service buyer on condition that the "embargo" carried out by traders and service providers can contain unstable market prices, even though the commodities, benefits, or services are very needed by the community, the state, and others (Hasan 2004). Judging from the above understanding, the one that includes ihtikar is the activity of stockpiling goods with the intention to dominate the market and sell the goods in order to get high profits when the goods become scarce.

\subsection{Ihtikar Law}

Muamalah is synonymous with economic transaction, which aims to achieve maximum value or profit. Basically everything in muamalah is punished halal until there are arguments stating that this is prohibited. Expect big profits not to be forbidden if they do not violate the rights of God and do not harm others. If seen in the Koran and the Hadith there is an Ihikar which is permissible and not forbidden as in Yusuf said, "So that you may plant seven years as usual, then what you reap should you let it be flown except for a little for you to eat. Then after that seven very difficult years will come, which consume what you save to face it (difficult year), except for a little of (the wheat germ) that you saved, then after that the year will come to which men will be given rain (with enough) and in those days they will squeeze wine. (Yusuf [11]:47-49).

In the verses above, it is explained that Yusuf advocated storing staple foods for seven years to meet the dry season. With the policy of storing basic food items applied by Prophet Yusuf, Egyptians survived the famine due to the long drought that had occurred. Hadith narrated from Umar bin Khattab, "The Prophet Muhammad once sold a plot of his dates which was on the plantation of Bani Nadhir. And he left dates for the needs of one year for himself and his family". (HR. Bukhari) (Tarmizi, 2018).

From the story that happened during the time of Prophet Yusuf, it describes a situation where at the time of harvest, it is recommended not to sell all of the wheat to face the difficult times that will occur. The reality is that when the harvest occurs, the price of the item will go down and the traders will solve it by hoarding some of the goods in order to get more profit if the goods are resold after the harvest period has passed. This problem does not include ihtikar which is prohibited because the stockpiling does not have an impact on the scarcity of goods resulting in soaring prices of goods. 
It can be seen from the two sources, that not all ihtikar are punished as haram, but there are several concepts of ihtikar that are permissible. The act of hoarding goods, whether staple food or money for future needs as above, is permissible if at the time of hoarding, the surrounding social and economic conditions during normal times and hoarding do not harm or affect the interests of the people. In Islam, the ihtikar law is haram. There are two opinions about the omission of Ihtikar. The first opinion is that which forbids ihtikar, they are Jumhur Syafi'i and the followers of Maliki, Hambali, Dzahiriyah and Zaidiyah.

Whereas the second opinion is the one who says that the legal ihtikar is karahah (hated) in terms of human food. They are some of the followers of Syafi'i and Hanafi followers. Islam explains that ihtikar is a hoarding of goods to be sold, which are goods that are needed by the public from the market circulation in a certain period until then the price is more expensive. When prices are expensive, the goods are just sold. (Masruroh, 2015).

One way to get big profits in prohibited buying and selling is ihtikar. Where a group of people control and regulate prices arbitrarily. They buy basic necessities from suppliers, then hoard them until they are scarce in the market. When rare goods are on the market and prices rise soaring they sell at very high prices, thus they generate huge profits (Tarmizi , 2018) One time the price of food ingredients soared at the time of the Prophet Muhammad. So some friends complained to the Prophet asking him to fix the price.

So the Prophet said, "Indeed, only Allah has fixed the price, He has restrained, He has spread and He has given sustenance. Indeed, I hope to meet Allah (in the end) without anyone claiming the evil I ask for property and soul (because of oppression traders by setting prices that certainly reduce profits for them)". (HR Abu Daud, pronounced saheeh by Al Albani). As the Prophet Muhammad did not want to tyrannize the merchants by lowering the profits they should get from rising prices, then he also did not want the traders to tyrannize the public with the ihtikar method so that the prices of basic necessities rose high which resulted in the decline in power buy money that is in the hands of many people. And many people will have difficulty fulfilling their basic needs to make a living, really ihtikar is a real act of injustice. Because of the large impact of ithtikar on the people, the Prophet Muhammad branded the culprit as a sinner, the Prophet said "Ihtikar will not be done except by a sinner" (HR. Muslim).

Aside from being labeled as a sinner, the ihtikar perpetrator deserves to be thrown into the deep pit of hell, because he has troubled many people to get basic necessities. The Prophet Muhammad said, "Whoever influences the price of Muslim food items so that it becomes expensive, is the right of God to throw it into a big place in hell later on the Day of Judgment" (HR Ahmad. Al Arnauth said, "This Sanad had jayyid"). Because the threat was so heavy for ihtikar perpetrators, Ibn Hajar Al Haitami classified this hoarding action into a great sin (Tarmizi, 2018). Termination points that can be taken if the ihtikar results in the loss of many people and the instability of market prices due to the stockpiling. So if there are no two elements then it is not a forbidden ihtikar, but a hoarding to prepare for the future. As An Nawawi said, "According to the scholars, the wisdom of hoarding goods is forbidden to make it difficult for human audiences. The scholars agree that someone who has large amounts of staple food while people are in a difficult season and desperately in need of basic food, food owners the excess may be forced by the authority to sell it, so that difficulties are lifted from the crowd " (Tarmizi, 2018).

\subsection{Ihtikar Object}

Based on the object, some scholars differ in opinion, namely: (1) The first group defines the ihtikar as stockpiling which is only limited to staple food, (2) The second group defines the Ihtikár, which is to hoard all human and primary needs, and (3) The third group of four schools all 
forbade the ihtikar for all types of goods, both basic and secondary, tertiary, which can cause harm to the community, including seeds according to Hanbali scholars (Rohman: 2017). The other opinions are: The first opinion: the ban on ihtikar specifically for staple foods only. This opinion is the Hanafi, Shafi'i and Hanbali schools. Because some of the traditions which forbid ihtikar are mentioned that the object is staple food. Among them are the words of the Prophet narrated by Umar bin Khattab "Whoever hoards the staple food of the Muslims, surely Allah will inflict on him leprosy and his trade will go bankrupt." (HR Ibn Majah Al-Bushairi said, "This Sanad hadith is jayyid").

Response: The word food mentioned in some traditions which forbids ihtikar cannot be understood that in addition to staple food, it can be hoarded, because in the science of ushul figh it is called the mafhum laqab and the declaration of laqab shows its meaning is not strong, therefore the object of absolute ihtikar is without restrictions. Second opinion: the absolute ihtikar object of any kind. This opinion is Maliki. The argument of this opinion is that some of the hadiths that explain the prohibition of absolute ihtikar, do not mention that the object is food. Then any kind of thing that is needed by the people is unclean. In accordance with the wisdom of prohibiting ihtikar, namely: not harming many people. So whatever the needs of the people may not be hoarded, such as fuel, building materials, certain national currencies and so on (Tarmizi: 2018).

In this problem the jurists differed on two things, namely the types of goods which are forbidden to hoard and the time forbidden by people to hoard. The scholars differed on the object piled up, namely: (1) the first group defines ihtikar as hoarding which is only limited to basic (primary) food ingredients, (2) The second group defines the Ihtikar, which is to hoard all human needs both primary and secondary. The group of scholars who define ihtikar limited to the staple food of Imam alGazali (the jurisprudent of the Syafi'i), some of the Hanbali where he argues that what is meant by ihtikar is only limited to staple food while in addition to staple food (secondary) such as drugs, herbs, etc. not including objects that are prohibited in stockpiling goods even though they are equally edible items because what is prohibited in the text is only in the form of food.

According to him the issue of ihtikar concerns the freedom of the owner of the goods to sell his goods. Then the ban must be limited to what is indicated by the text. While the group of scholars who define ihtikar broadly and generally among them is Imam Abu Yusuf (Hanafi school of jurisprudence), the Maliki school believes that the ban on ihtikar is not only limited to food, clothing and animals, but includes all products needed by the community. Decreasing, which becomes "ilat (legal motivation) in the prohibition on doing the ihtikar is the harm that afflicts many people. Therefore the harm that afflicts many people is not only limited to food, clothing and animals, but includes all products needed by many people (Dahlan 1996).

Al-Syawkani does not specify what products are stored so a person can be said to be an ihtikar actor, if he keeps the item for sale when the price soars. Even al-Syawkani does not distinguish whether hoarding occurs when the market is in a normal or unstable market condition. This needs to be distinguished because according to the number of scholar if the attitude of the traders in storing goods is not to damage market prices there is certainly no prohibition.

According to Fathi al-Duraini, al-Syawkani belongs to the group of scholars' which forbids ihtikar on all objects or goods needed by many people. The part of Hanbali and al-Ghazali' resolved the prohibition of ihtikar on only basic types of food. Al-Ghazali said that as for nonstaple food and not as a substitute for staple foods such as medicines and herbal medicine, there is no prohibition even though he is an edible item. As for the inclusion of staple foods such as meat, fruits and which can replace staple foods in a condition even if not continuously, 
then this includes things that are of concern so that some of the scholars have stipulated that they are forbidden to store samin oil, honey, peanut oil and other items that are human needs (Maulidizen 2017).

From al-Ghazali's explanation, Yusuf Qarhdawi considered that some fuqaha considered staple food to be limited to snacks such as bread and rice or rice without oil and side dishes. So that cheese, olive oil, honey, seeds and the like are considered outside the category of staple food. What they mentioned as staple food according to modern science is not enough to be a healthy food for humans because to be a healthy food must fulfill a number of basic elements such as protein, fat, and vitamins. If not, then humans will subject to disease due to poor food conditions.

\subsection{Factors occur ihtikar}

Factors Causing the Occurrence of the ihtikar An enterprise can obtain a condition such as the characteristics of the landfill above because it is caused by many things. The things that allow the arising of hoarding in general are: (1). The producer has patent rights for the output produced. Such as author rights, trademarks, names of meat, (2) Producers have one of the most important resources and keep it confidential or producers have other knowledge than others about the technical production, (3) Special government grants to certain producers to manage certain businesses as well, (4) The size of the market is so small as to be served by more than one company that operates the optmm company scale. In fact, markets are sometimes obtained which are only possible to be served by a company that operates an optimum production scale, for example in the fields of transportation, electricity and communication. The emerging monopoly market is often called natural monopoly, and (5) The government sets a limitation of pricing policy. The policy of price limitation (pricing at the lowest possible level) is intended to prevent new companies from entering the market. The pricing policy is usually accompanied by a large-scale sales promotion policy. (Rohman: 2017)

\subsection{Ihtikar Criteria in Islam}

In this case the ulama argue, that what is meant by hoarding is illegitimate which has the following criteria: (1) That the goods stockpiled are the excess of their needs and the dependents for full-year inventory. Because a person can hoard for his and his family's livelihood in less than one year, (2) That the person is waiting for the peak times of the price of the item to be able to sell it at a higher price because people really need the item to him, (3) That landfilling is done at a time when humans really need goods to be stockpiled, such as food, clothing and others. If the items in the hands of the merchants are not needed by humans, then they are not considered hoardings, because they do not cause difficulties to humans (Sabiq 1981, Hasan 2004).

Of the three conditions, it can be concluded, that hoarding that is forbidden is the excess of the necessity of earning himself and his family in one year. This means that when hoarding consumer goods to fill the needs of the family and themselves within one year is not prohibited because it is a reasonable action to avoid economic difficulties in times of famine or other economic crises. Whereas the conditions for hoarding are arriving at a boundary that makes it difficult for local residents to buy goods that are piled up solely because the fact that the stockpiling will not occur other than in this kind of situation. If, if it is not difficult for the local people to buy the item, then the hoarding of goods will not be arbitrary towards the item so that it can be sold at a price that is expensive (Pasaribu 2004).

On this basis, the conditions for the hoarding are not purchases of goods. But it is just collecting goods by waiting for the price to rise so that they can sell at a more expensive price. It is said to hoard in addition to the results of the purchase also because of the extensive yield of the produce while only he has the type of produce, or because of the scarcity of these plants. It can also be hoarded because of its 
industries while only he has the industry, or because of the scarcity of industry as he has. According to Yusuf al-Qardawi the stockpiling is forbidden if it has keriteria as follows: (1) Performed in a place where the population will suffer because of the landfill, (2) Hoarding is done to increase prices so that people feel difficult and so that he can get multiple benefits (Qardhawi 2000). According to the scholars, Syafi'i stated that the forbidden ihtikar is the accumulation of certain basic items, namely buying them at a time when prices are high and selling them back. He didn't sell right away, but he kept it until the price jumped up. But if he brings in goods from his village or buys them at a low price then he saves them because of his needs, or he resells them at that time, then it is not ihtikar and is not forbidden. As for other than food ingredients, it is not forbidden to hoard in any condition.

\subsection{The Similarities and Differences Between} Ihtikar and Monopoly

Ihtikar and monopoly have several similarities and differences. The equation between Ihikik and monopoly is (1) Monopoly and ihtikar both have an element of unilateral interest in playing with prices, (2) Monopolists and ihtikar both have the option of offering goods to the market or not offering them, (3) Monopoly and ihtikar can result in loss of dissatisfaction with the community. In addition to some of the above equations, there are also some differences between monopoly and ihtikar. That monopoly occurs if a person has large capital and can produce certain goods on the market that are needed by the community, while (1) ihtikar can not only be done by large capital owners but middle-income capital even so can do it, (2) A monopolist company tends to carry out economic activities and pricing according to government regulations (the existence of government standard regulations), whereas ihtikar can be done by anyone, because hoarding is very easy to do, (3) To get the maximum profit, in the ihtikar the scarcity of goods and the increase in the price of an item occur in a time and time that is tentative and sudden and can lead to inflation. While the monopoly on price increases usually tends to be influenced by the high production and operational costs of a company even though sometimes it is also affected by scarcity of goods, (4) Monopoly practices are legal and even in certain countries are protected by laws or rules of a country, while ihtikar is illegal economic activity (Iswardono 1990).

\subsection{Problems in ihtikar}

\subsubsection{Saving Food for a Year's Needs or Saving} for Tomorrow's Needs, Is It Included in the Ihtikar?

Every human being is accustomed to planning for the future and striving hard at this time to fulfill tomorrow's needs. Saving the proceeds from work or even buying food supplies is a common thing to do so in carrying out his life to live tomorrow is stable because it has been prepared. This problem is not included in the ihtikar prohibition, because this activity does not create major changes in market prices or even detrimental to the surrounding. Even the act is recommended, because the future is something unknown and we are told to prepare tomorrow as well as possible.

It is narrated in the story of Sa'ad bin abi Waqqash who wanted to have more than one third of his wealth, so the Prophet forbade and said "It is worth a third and a third is enough. As much as possible. If you leave your warrior expert in a rich state better than you leave them in poor condition, they extend their hands to humans" (HR Bukhari and Muslim).

From the above hadith it can be understood that Saad bin abi Waqqash is a rich man who saves his wealth beyond his needs, even though he has inherited $1 / 3$ of his wealth but the recipient of his inheritance is still considered rich in inheritance but received. So if you save the forbidden treasure, the Prophet will tell Sa'ad to have more wisdom in retaliation for bad actions. But as a Muslim there is an obligation to pay alms if he keeps something in a certain period of time and a certain amount. 
If saving and storing food if the amount saved is less than one zakat, which is: 20 Dinar (+ -85g) gold and 300 sha '(+ -617kg) the staple food of all the ulama agrees that the law may be due to the assets below zakat tab is considered a little. If you reach Nishab, then the zakat must be issued. If it is not issued, the stored assets will turn into a punishment for the owner. Allah says "And those who save gold and silver will not spend it on the path of Allah, then tell them (that they will get a painful punishment), on the heated day the silver of gold in Hell will be burned with their foreheads, stomachs and their backs (then said) to them. "This is your property that you have saved for yourself, then feel now (the result of) what you have saved" (At Taubah: [9]:34-35). However, if the assets saved have been paid zakat, then the property may be saved no matter how much, if it does not damage the market price and there is no intention to seek profits from the scarcity of goods. (Tarmizi, 2018)

3.7.2. Saving Goods for Sale When Prices Rise, Is the ihtikar Included?

The scholars agreed that ihtikar was forbidden because it harms the public. Where is the action causing rare goods and rising prices to soar?. If a trader buys an item when it's cheap, then keeps it until the price rises and is sold at that time according to the market price, this action does not include ihtikar. With a note, this action does not harm the people and does not damage the price, because the goods are still sold in the market by other traders. It is reported that $\mathrm{Abu}$ Zinad questioned the action of Sa'id Musayyib (died: $94 \mathrm{H}$ ) storing basic food items, even though he had narrated the hadith of the ihtikar prohibition. Ibn Musayyib answered "This is not ihtikar. The meaning of the Prophet with ihtikar is buying goods when the price is high and this action will certainly increase prices to be even higher. this is a virtue" (This Atsar is narrated by Baihaqi).

Ibn Musayyib considers this action to be a virtue, because the actions of traders keep selling it when people need it, including in order to maintain the existence of goods every season. If this is not done, surely the items will be very rare outside the harvest season and high prices. Conversely, in the low season harvest prices can even be wasted. The consequences if there is no temporary storage action are certainly not in accordance with Islamic teachings that prohibit redundant acts (Tarmizi, 2018). The increase in the price obtained is also allowed instead of the cost of storage and as a seller's profit if indeed the price of the item at that time does indeed increase. This activity is one of the ways that sellers usually do to get bigger profits and this is allowed. Imam Malik was asked about people who store goods, whose actions do not interfere with market prices. He replied, "The actions they do may while not damaging the market" (Tarmizi, 2018).

Table 1 Comparison of the Four Sects of the ihtikar Concept

\section{Comparative Review}

Definition

\section{Hanafi}

Hoarding of everything that can cause harm in a particular region or country in the form of economic instability in the community in the form of food, clothing, dinar, and dirham money.

\section{Maliki}

Stockpiles of goods for sale and profit seeking by utilizing the price volatility of these items in the market.

\section{Syafi'i}

Selling food when the price rises and holds it or keeps it in order to increase the selling price later.

\section{Hanbali}

The accumulation of goods obtained through the purchase of the conditions of the community is in need, which results in a narrowing of 
Jurnal Ilmiah Ekonomi Islam, 5(02), 2019, 97

\begin{tabular}{|c|c|}
\hline Comparative Review & Mazhab \\
\hline & $\begin{array}{l}\text { the movement of the community in obtaining these items, so that they will } \\
\text { influence the economy of the community in that area. }\end{array}$ \\
\hline Law of ihtikar & $\begin{array}{l}\text { Hanafi: Makruh Takrimah } \\
\text { Maliki : Haram } \\
\text { Syafi'i : Haram } \\
\text { Hanbali: Haram }\end{array}$ \\
\hline
\end{tabular}

Types of Goods Banned

\section{Hanafi}

1. All materials or goods that can cause economic instability in the community.

2. Food, clothing, cash, and dirhams. (if not disturbing, it is allowed to hoard)

\section{Maliki}

1. Everything or goods that can create an economic danger to the community.

2. Foodstuffs, spices, imported food and other items needed by the community including linen, cotton, even in the form of cloth or

\section{Syafi'i} currency.

1. All types of food ingredients that can cause harm to the community.

2. All goods needed by the community

\section{Hanbali}

1. 1. All types of food that can cause harm to the community.

2. Food ingredients, such as grains and some that are needed by the community

Allowed Period

\section{Hanafi}

1. As long as the item does not cause danger to the community.

2. The period of time allowed to hoard for 40 days or one month.

\section{Maliki}

1. 1.As long as the item does not cause danger to the community.

2. Not in difficult times.

\section{Syafi'i}

1. As long as the item does not cause danger to the community.

2. When prices are low

3. When the community does not need the items specified.

\section{Hanbali}

1. As long as the item does not cause danger to the community.

2. 2. When the condition of the community is fulfilled

Regional Provisions

\section{Hanafi}

Affirming small economies with weak economies

Maliki

Not decisive

Syafi'i

Not decisive

\section{Hanbali}

It should not be done in small economies with weak economies, such as Mecca and Medina. Republished in a country that has a wide door to import goods such as Baghdad, Damascus, Cairo.

\subsection{Ihtikar sanctions}

Seeking profit is something that is permissible, but if it violates a law which has been determined as by the ihtikar method then in the Quran it is stated that the ihtikar perpetrators will get a painful punishment in the form of 
being put into hell. Whereas in the world the scholar agreed that the authorities in this matter had the right to force the ihtikar perpetrators to sell the goods he had accumulated at a price set by the party so as not to harm the public and to stabilize prices at that time but not to eliminate the seller's right of profit. If the offender refuses to sell it, the offender is allowed to be given a prison sentence until he wants to sell the item. In Article 17 paragraph 1, Law No. 5 of 1999 stated: "Business actors are prohibited from exercising control over the production and or marketing of goods and or services that can result in monopolistic practices and or unfair business competition." And, Article 47 and 48 of the 1999 Law are mentioned, if there is a violation of the law. - the law allows the government to impose sanctions on the perpetrators, both administrative sanctions (agreement failure or fines as low as IDR 1,000.000000.00 and a maximum of IDR $25,000,000,000.00$ IDR $1,000,000,000.00$ and sanctions in the form of minimum confinement of 3 months to 6 months.

\subsection{Impact of Ihtikar practices in the economy}

The status of property ownership is the right of the owner. In the economic process, there is an activity that aims to gain profit. Isalam does not prohibit people from increasing their assets by gaining profits in buying and selling transactions. Obtaining a large profit is the desire of every buying and selling agent, where he gets the benefits that are worth the effort to run the process. In Islam, a property generated from the existence of the process is permissible. As in producing an item and the price of the item increases because of the process. But in seeking the maximum profit Islam also confirms that it should not violate the stipulated conditions which do not harm other people or in ways that are not fair.

One of the ways is to get a large profit but is not justified in Islam by using the capitalist system. That is, a system that justifies all means to achieve maximum profits without regard to social as a form of monopoly where in a state of urgency the community has no choice but to buy. Every human being has the right to channel his property according to what he wants himself, whether raising the original price does not have an impact on society, but is also not permitted at a low price, because it will harm the seller. Is it hoarded or sold at prices as expensive - the thing. If it has entered the ihtikar dosage, then the problem discussed is no longer about the right to freedom of distribution.

The practice of Ihtikar which is prohibited in religion, of course has a great effect on the economy of the community, because of the high cost of basic goods which are human needs. Every day will demand the soaring value of bargains of other goods, due to the impact of the increase in the price of one item. In economic law, it is explained that when demand increases and goods decline, prices will increase. This increase will have a broad impact. Based on economic law, the less the availability of goods in the market, the price of goods increases and the demand for goods decreases. Goods suppliers can sell their goods at a price higher than the normal price. The seller will get a profit greater than the normal profit, while the buyer will suffer losses. So, due to the ihtikar, the people will be harmed by the actions of a small group of people.

Therefore, in a monopoly market, a supplier of goods can act as a price maker. In such situations and conditions that are felt to be all difficulties and shortcomings. A further implication, Ihtikar will not only damage the market mechanism, but also will stop the benefits that will be obtained by others and can hinder the process of distribution of wealth among humans. Because the buyer still has to pay the product price which is higher than the marginal cost. Thus the practice of ihtikar will hamper people's welfare. Though one of the objectives of the economic system, whatever its form is the welfare of the people of the community. The point is ihtikar can damage the market system that has been running normally. As discussed above, some scholars state that ihtikar is of 
various forms and is not limited to staple foods. Broadly speaking, market imperfections occur because of three things.

First, structured deviations. A market will disrupt the market mechanism in a systematic and structured way too. The intended market structure is monopoly and unhealthy competition. This market structure is a prohibition in Islam, because in addition to damaging the market system it is also opposed to maqashid sharia. Second, storage is unstructured, namely the presence of incidental and temporary internal factors that disrupt the market system, for example ihtikar, najasyi, tadlis, collusion of traders to make prices above normal. Such a system also contradicts the goals that have been regulated by the Sharia.cThird, information imperfections and adjustments. This is like what happens when buying goods from a producer while still in the middle of the road (not in the market), buying from someone who is ignorant who does not understand the actual market price (al-ghubn). These three things that can damage the market must be avoided and prohibited in Islam. Therefore, every seller and buyer must be careful in carrying out the transaction. The prohibition contained in this religion does not expressly sanction, but the penalty is in the form of haram, the effect of which is afterlife. Therefore, as a market player, we must always prioritize the transcendence system as discussed above (Muslim, 2010).

\subsection{Role of the Government}

Islam allows the state to regulate economic problems so that the needs of the community both individually and socially can be met proportionally. Islam considers that the state is obliged to protect the interests of the community from injustices committed by someone or a group of people or from another country. The state is also obliged to provide social security so that all people can live properly. Therefore, it is only natural that the Indonesian state in the 1945 Constitution states: (1) The economy is structured as a joint effort based on the principle of family, (2) Production branches that are important to the state and which control the livelihood of many people are controlled by the state, (3) Earth and water and the natural resources contained therein are controlled by the State and are used for the greatest prosperity of the people (Djazuli 2006).

In Islam, types of ownership are known, namely private ownership, public ownership and State ownership. Whereas state property is a property that belongs to all Muslims, while the one who manages is the obligation of government officials. These assets, for example war booty, jiz'yah and inside include water, air, fire which are common, but the state has the right to regulate its regulations. Therefore, it is the authority of the state to make strict regulations for hoarders to share their interests. the government must supervise the market. This market oversight is useful to ensure the market mechanism runs perfectly. During the time of the Prophet, among others, conducting direct inspections to the market to see prices and market mechanisms. If there is a price that is not in accordance with the market mechanism, then the Messenger of Allah rebukes the culprit and gives advice on good market behavior.

Therefore, a monitoring sequence is needed to prevent ihtikar practices; (1) Organizing the market so that it can function as a solution to people's economic problems through a healthy market mechanism, (2) Ensure instruments for prices of goods and services determined in accordance with the law of supply and demand, (3) Supervise products that enter the market, (4) Providing information on the market regarding market prices and systems, (5) Ensure the absence of monopolistic practices by market participants, (6) Oversee brokering practices in the market, and (7) Seek Islamic morals, especially those relating to market mechanisms. With this series, it will make the market run well. So actions and precautions can be taken to guarantee the absence of fraud, fraud and various other practices that can damage the market system. (Muslim: 2011) 
The action that can be taken by the government against ihtikar perpetrators is to sell stockpiled merchandise according to the market price at that time and profit from the sale, then the proceeds of the sale are given to the poor. While the ihtikar perpetrators are only entitled to get the basic capital. Furthermore, the government will give a warning. If the warning is not addressed, the government has the right to give a sentence. The state as regulator of trade regulations must provide supervision and regulation through laws or other government regulations to regulate the market system so that it can run well. Among the systems that can be implemented are fair business competition regulations.

In this case the state can issue a regulation on the game of fair business competition, by prohibiting the following: (1) Prohibition of conducting business conspiracies that harm other competitors, (2) Monopoly or obtain special rights on the basis of KKN with bureaucrats, (3) A non-transparent tender process, or using an alibaba company, (4) Price differentiation in certain business groups that harm competitors, and (5) Production processes, product quality, and advertising campaigns that harm consumers.

\subsection{Lessons from the Prohibition of ihtikar}

Imam Nawawi explained the wisdom of the prohibition on doing ihtikar is to prevent things that make it difficult for humans in general, therefore the scholars agree that if there are people who have more food, other humans are starving and there is no food except those of the person, it is obligatory for the person sells or provides free food to humans so that humans have no difficulty. Likewise, if someone hoards other than food (such as winter clothes and so on) so that people have difficulty getting it, and endanger them, then this is prohibited in Islam. Islam prohibits people from hoarding and preventing property from circulation. Islam threatens those who hoard it with a torment poignant on the Day of Judgment. Allah says in the letter of At Taubah verses 34-35: Meaning: "And those who save gold and silver and do not spend them on the path of Allah, tell them (that they will get) a painful torment. On the day that silver gold was heated up in hell, then they burned their foreheads, their stomachs, and their backs (then said to them): "This is your treasure which you have saved for yourself, then what is it that you save it". Heap treasure means to freeze it, hold it back and keep it from circulation. In fact, if the assets are included in productive businesses as in production planning, there will be many new job opportunities and reduced unemployment (Maulidizen 2016).

New opportunities for this work can increase the income and purchasing power of the community so that it can encourage increased production, both by making new plans and by expanding existing plans. Thus, a situation of economic growth and development will be created in society. Stockpiling of goods is the biggest obstacle in regulation competition in the Islamic market. In the international level, hoarding goods become the biggest cause of the crisis experienced by humans now, where some economically and richly developed countries monopolize production, trade, basic materials and basic needs. In fact, these countries monopolized the purchase of raw materials from countries with less developed economies and monopolized the sales of industrial commodities needed by these countries. That poses a great danger to the fair distribution of wealth and income at the world level.

\section{Conclusion}

Ihtikar is "Selling raw materials when prices rise and holding them or storing them to increase the selling price later." Ihtikar "Everything that can cause harm to people in a particular region or country or community environment in the form of food, clothing, dinar and dirham money . ihtikar is "Hiding certain items in the market which aims to obtain high price benefits." Stockpiling of goods obtained through purchases when the conditions of the middle society are in need which results in a narrowing of the movement of the community in obtaining these goods, so that it will affect the economy of the area." 


\section{References}

Dahlan, Abdul Aziz. (1994). Ensiklopedia Hukum Islam. Jakarta: PT. Ikhtiar Baru.

Djazuli. (2006). Kaidah-kaidah Fiqh: Kaidahkaidah hukum Islam Dalam Menyelesaikan Masalah yang praktis. Jakarta: Kencana Prenada Media Grup.

Djuwaini, Dimyauddin. (2008). Pengantar Fiqh Muamalah . Yogyakarta: Pustaka Pelajar.

Hasan, Ali. (2004). Berbagai macam transaksi dalam Islam. Jakarta: PT. Raja Grafindo Persada.

Iswandono. (1990). Ekonomi Mikro. Yogyakarta:UPP AMP YKPN.

Masrusoh, Nikmatul. (2015). "Larangan Ihtikar di Indonesia”. Interest, Vol.13, No. 1

Maulidizen, A. (2016). Riba, Gharar dan Moral Ekonomi Islam dalam perspektif sejarah dan komparatif: Satu sorotan literatur. Islamiconomic: Jurnal Ekonomi Islam, 7(2): 141-164

(2017). Studi Pemahaman Kontemporer Tentang Nilai-nilai Moral Dalam Eknomi Islam. Hukum Islam, 16(2), 130-150.
Muslim, Mochammad Bukhori. (2011). "Ihtikar dan Dampaknya terhadap Dunia Ekonomi." Universitas Islam Negeri Syarif Hidayatullah Jakarta.

Pasaribu, Chairuman. (2004). Hukum Perjanjian Dalam Islam. Jakarta: Sinar Grafika.

Rohman, Muhammad Taufiqur. (2017). "Perbandingan Konsep Ihtikar Menurut Pendapat Fiqih Empat Mazhab dan Konsep Penimbunan Barang Menurut Hukum Positif." Universitas Islam Negeri Maulana Malik Ibrahim Malang

Sabiq, Sayyid. (1981). Fiqh al-Sunnah. Libanon: Dar al-Fikr.

Tarmizi, Erwandi. (2018). Harta Haram Muamalat Kontemporer. Bogor: P.T Berkat Mulia Insani

Yusuf al-Qardhawai. (2000). Halam Haram Dalam Islam. Surabaya: PT. Bina Ilmu 